\title{
Penerapan Discovery Learning dengan LKS untuk meningkatkan hasil belajar siswa kelas IV SDN 02 Krompeng
}

\author{
Aliyah \\ SDN 02 Krompeng, Talun, Kabupaten Pekalongan
}

\begin{tabular}{|c|c|}
\hline Article Info & ABSTRACT \\
\hline Article history: & \multirow{4}{*}{$\begin{array}{l}\text { The purpose of this study was to determine the improvement of student } \\
\text { learning outcomes at SDN } 02 \text { Krompeng Talun through the application of } \\
\text { Discovery Learning. The type of research that will be conducted is classroom } \\
\text { action research. The subjects of this study were the fourth grade students of } \\
\text { SDN } 02 \text { Krompeng, Talun, Pekalongan Regency, totaling } 25 \text { students . The } \\
\text { results of the study showed an increase in learning outcomes and student } \\
\text { activeness in learning. In sikus I value - average grade of } 69.5 \text { p er sentase } \\
\text { classical learning completeness } 68 \% \text { and per sentase overall activity of } 71.4 \% \text {. } \\
\text { In the second cycle the average value of the class is } 83.4 \text { with a per sentase } \\
\text { completeness of classical study } 88 \% \text { and persentase overall activity of } 77.3 \% \text {. } \\
\text { Thus it can be concluded that discovery learning with worksheets can improve } \\
\text { student learning outcomes. Therefore, it is suggested that as teachers should } \\
\text { be able to apply discovery learning as an alternative to improve learning } \\
\text { outcomes in the form of cognitive abilities and increase student activity. }\end{array}$} \\
\hline $\begin{array}{l}\text { Received : } 30 \text { Juli } 2021 \\
\text { Revised : } 1 \text { September } 2021 \\
\text { Accepted : } 20 \text { September } 2021\end{array}$ & \\
\hline & \\
\hline $\begin{array}{l}\text { discovery learning; activity; } \\
\text { learning outcomes; students }\end{array}$ & \\
\hline
\end{tabular}

(*) Corresponding Author:

aliyahkhafidz@gmail.com

How to Cite: Aliyah. (2021). Penerapan Discovery Learning dengan LKS untuk meningkatkan hasil belajar siswa kelas IV SDN 02 Krompeng. Action Research Journal, 1(1): 1-5.

\section{PENDAHULUAN}

Pembelajaran tematik merupakan pendekatan pembelajaran yang mengintegrasikan berbagai kompetensi dari berbagai mata pelajaran. Pengintegrasian tersebut dilakukan dalam 3 (tiga) hal, yaitu integrasi sikap, kemampuan/keterampilan dan pengetahuan dalam proses pembelajaran serta pengintegrasian berbagai konsep dasar yang berkaitan. Trianto (2010) menjelaskan bahwa proses belajar terjadi melalui banyak cara baik disengaja maupun tidak disengaja dan berlangsung sepanjang waktu dan menuju pada suatu perubahan tingkah laku yang baru keseluruhan. Ini menunjukkan bahwa kegiatan belajar merupakan suatu proses perubahan sebagai hasil dari interaksi dengan lingkungan (Supriyadi, 2012; Jiwandana, 2013).

Dalam pelaksanaan pembelajaran IPA yang dilakukan di kelas IV SDN 02 Krompeng, pendekatan sintifik masih kurang diterapkan. Hal itu juga disebabkan karena dalam menerapkan pembelajaran dikelas masih berpusat pada guru. Dampaknya adalah hasil belajar siswa IPA kurang dari KKM, seperti: siswa kurang berani bereksplorasi, kurang terampil, kurang aktif dalam memyampaikan pendapat, dan siswa cenderung bersikap pasif. Ini ditunjukkan dengan hanya 15 siswa atau setara 60\% siswa yang mencapai ketuntasan belajar dengan nilai rata-rata hanya 60,5. Selain itu, keaktifan siswa juga salah satu faktor yang mempengaruhi rendahnya hasil belajar yang diperoleh oleh siswa. Meningkatnya aktivitas belajar siswa diharapkan sejalan dengan meningkatnya pemahaman siswa akan suatu materi IPA yang diajarkan. Menurut Jiwandana (2013) belajar adalah berbuat sekaligus merupakan proses yang membuat anak didik harus aktif. Dari pengertian ini dapat diketahui bahwa aktivitas belajar siswa merupakan hal yang harus ditingkatkan dalam proses.

Discovery Learning merupakan salah satu pembelajaran yang memungkinkan siswa terlibat langsung dalam kegiatan belajar mengajar, sehingga mampu menggunakan proses mentalnya untuk menemukan suatu konsep atau teori yang sedang dipelajari (Illahi, 2012; 
Putrayasa et al., 2014; Hidayat, Mawardi, \& Astuti, 2019). Discovery merupakan pembelajaran yang memajukan cara belajar aktif, berorientasi pada proses, mengarahkan sendiri, dan mencari sendiri. Dengan demikian metode discovery adalah suatu metode yang di mana dalam proses belajar mengajar guru memperkenankan siswa menemukan sendiri informasi. Pembelajaran yang menempatkan guru sebagai fasilitator, dimana siswa menemukan sendiri pengetahuan yang belum mereka ketahui dengan dibimbing oleh pertanyaan guru dan LKS (Rosarina et al., 2016; Setiani, Koeswanti, \& Radia, 2019). Pengetahuan baru akan melekat lebih lama apabila siswa dilibatkan secara langsung dalam proses pemahaman dan 'mengkontruksi' sendiri konsep dan pengetahuan tersebut. Dalam penerapan discovery, guru membimbing siswa dan siswa didorong untuk berpikir sendiri sehingga dapat menemukan prinsip umum berdasarkan bahan yang disediakan oleh guru dan sampai seberapa jauh siswa dibimbing tergantung pada kemampuannya dan materi yang sedang dipelajari (Markaban, 2006; Susanti, Harjono, \& Airlanda, 2018; Hidhayah, Slameto, \& Radia, 2018).

Discovery Learning adalah pembelajaran dimana siswa membangun pengetahuan mereka sendiri dengan mengadakan suatu percobaan dan menemukan sebuah prinsip dari hasil percobaan tersebut (Hidhayah, Slameto, \& Radia, 2018; Sudirama, Japa, \& Yasa, 2021). Penerapan model pembelajaran discovery learning di SD terutama pada mata pelajaran IPA menjadi sangat tepat dikarenakan model pembelajaran ini memiliki beberapa kelebihan. Pembelajaran discovery learning memiliki beberapa kelebihan, yaitu: 1) menambah pengalaman siswa, 2) menggali kreatifitas siswa, 3) meningkatkan rasa percaya diri pada siswa, dan 4) meningkatkan kerja sama antar siswa. Hal tersebut lebih didukung lagi berdasarkan beberapa hasil penelitian yang pernah dilakukan dengan menerapkan model pembelajaran discovery learning. Beberapa hasil penelitian menjelaskan bahwa hasil belajar dalam pembelajaran IPA setelah diterapkan model pembelajaran discovery learning mengalami peningkatan yang signifikan (Putrayasa et al., 2014). Berdasarkan uraian di atas, maka rumusan masalah dalam penelitian ini adalah apakah penerapan pembelajaran discovery melalui LKS dapat meningkatkan hasil belajar siswa kelas IV SDN 02 Krompeng?

\section{METODE}

Jenis penelitian ini adalah Penelitian Tindakan Kelas (PTK). Arikunto (2010) menjelaskan PTK merupakan suatu pencermatan terhadap kegiatan belajar berupa sebuah tindakan, yang sengaja dimunculkan dan terjadi dalam sebuah kelas secara bersama. Penelitian dilaksanakan dalam dua siklus dengan maksud untuk mengetahui perkembangan perubahannya dan dapat melakukan tahapan perbaikan dengan baik. Masing-masing siklus memiliki barbagai tahap yaitu dari tahap perencanaan, pelaksanaan tindakan, pengamatan, dan refleksi (Gambar 1).

Subjek dalam penelitian ini adalah siswa kelas IV SDN 02 Krompeng, Talun Kabupaten Pekalongan yang berjumlah 25 siswa. Metode pengumpulan data yang digunakan dalam penelitian ini yaitu tes dan observasi. Data tentang hasil observasi terhadap pelaksanaan penelitian digunakan untuk mengetahui aktivitas dan keterampilan siswa dalam mengikuti kegiatan belajar mengajar yang diperoleh dari data hasil observasi. Sedangkan tes digunakan adalah ulangan dengan bentuk soal uraian yang diberikan pada akhir siklus. Tes ini digunakan untuk mengetahui perubahan prestasi belajar siswa dengan penggunaan pembelajaran Discovery.

Teknik analisis data yang digunakan adalah deskriptif baik secara kualitatif maupun kuantitatif. Untuk tes hasil belajar siswa, dihitung jumlah skor dari masing-masing siswa dengan rumus rata-rata sebagai berikut.

Mean $=\frac{\sum x}{N}$

Keterangan:

Mean = nilai rata-rata siswa

$\sum x \quad=$ jumlah nilai seluruh siswa

$N \quad=$ jumlah siswa 
Untuk menghitung persentase ketuntasan klasikal kelas dapat ditentukan menggunakan rumus sebagai berikut.

$\underline{\text { Siklus I }}$

$$
\text { Persentase }=\frac{\text { jumlah siswa yang tuntas atau belum tuntas }}{\text { jumlah seluruh siswa }}
$$

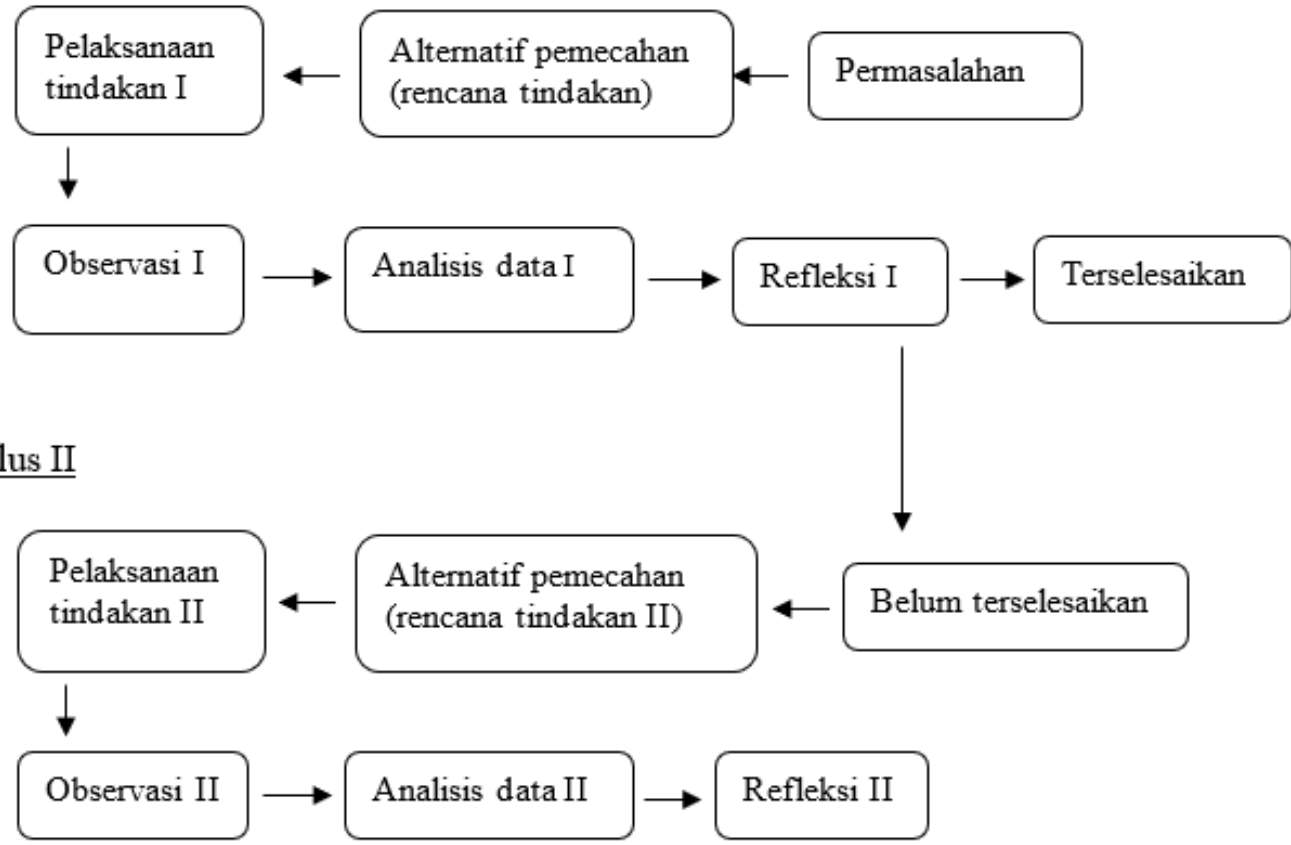

Gambar 1. Siklus Penelitian Tindakan Kelas

Kriteria keberhasilan yang ditetapkan dalam penelitian ini adalah ketuntasan belajar individu jika proporsi jawaban siswa yang benar lebih dari KKM yang telah ditetapkan dan untuk ketuntasan belajar klasikal jika minimal $85 \%$ siswa mendapat nilai diatas KKM yang telah ditetapkan yaitu 70, dan Keaktifan siswa dalam mengikuti proses pembelajaran matematika meningkat dengan persentase minimal $75 \%$ dari skor maksimal.

\section{HASIL DAN PEMBAHASAN}

Hasil penelitian dari siklus I dan siklus II menunjukkan bahwa pembelajaran dengan discovery menggunakan LKS dapat meningkatkan hasil belajar siswa. Hal ini ditunjukkan dari hasil analisis evaluasi pada siklus I dengan rata-rata hasil nilai siswa 69,5 dengan ketuntasan klasikal 68\%, sedangkan hasil analisis evaluasi siklus II diperoleh nilai rata-rata siswa 83,4 dengan ketuntasan klasikal 88\% sehingga indikator keberhasilan tercapai. Hal ini ditunjukan pada Tabel 1.

Tabel 1. Ketuntasan Belajar

\begin{tabular}{lccc}
\hline & Pra Siklus & Siklus I & Siklus II \\
\hline Jumlah Siswa Tuntas & 15 & 17 & 22 \\
Persentase Siswa Tuntas & $60 \%$ & $68 \%$ & $88 \%$ \\
Jumlah Siswa Tidak Tuntas & 10 & 8 & 3 \\
Persentase Siswa Tidak Tuntas & $40 \%$ & $32 \%$ & $12 \%$ \\
Rata-rata nilai & 60,5 & 69,5 & 83,4 \\
\hline
\end{tabular}

Pada Tabel 1 terlihat adanya peningkatan ketuntasan belajar klasikal dari siklus 1 sebesar $68 \%$ dengan jumlah siswa yang tuntas sebanyak 17 siswa menjadi $88 \%$ dengan jumlah siswa yang tuntas 22 siswa. Rata - rata kelas juga mengalami peningkatan dari $69,5 \%$ pada siklus 1 meningkat menjadi $83,4 \%$ pada siklus 2 . Peningkatan hasil belajar siswa ini dikarenakan adanya variasi dalam proses pembelajaran berupa penerapan pembelajaran discovery dengan LKS, 
supaya guru lebih memberikan kesempatan pada siswa agar lebih aktif dan dapat menemukan masalah sendiri dalam pembelajaran (Supriyadi, 2012; Jiwandana, 2013).

Keaktifan siswa secara keseluruhan selama proses pembelajaran mengalami peningkatan dari sikus I yang hanya $71,4 \%$ menjadi $77,3 \%$ pada siklus II, seperti yang dapat dibaca pada Tabel 2.

Tabel 2. Keaktifan Siswa

\begin{tabular}{lclc}
\hline \multicolumn{1}{c}{ Siklus I } & Persentase & \multicolumn{1}{c}{ Siklus II } & Persentase \\
\hline Keaktifan siswa dalam bertanya & $69,5 \%$ & Keaktifan siswa dalam bertanya & $76,6 \%$ \\
Keaktifan siswa dalam menjawab & $71,1 \%$ & Keaktifan siswa dalam menjawab & $78,9 \%$ \\
Keaktifan siswa dalam berdiskusi & $73,4 \%$ & Keaktifan siswa dalam berdiskusi & $78,1 \%$ \\
Keaktifan siswa dalam perhatian & $74,2 \%$ & Keaktifan siswa dalam perhatian & $78,9 \%$ \\
Keaktifan siswa dalam berpendapat & $69,5 \%$ & Keaktifan siswa dalam berpendapat & $74,2 \%$ \\
Rata-rata persentase & $71,4 \%$ & Rata-rata persentase & $77,3 \%$ \\
\hline
\end{tabular}

Berdasarkan Tabel 2 keaktifan siswa dalam bertanya meningkat dari siklus 1 sebesar $69,5 \%$ meningkat menjadi $76,6 \%$ pada siklus 2 , keaktifan siswa dalam menjawab meningakat dari $71,1 \%$ pada siklus 1 menjadi $78,9 \%$ pada siklus 2 , keaktifan siswa dalam berdiskusi meningkat dari73,4\% pada siklus 1 menjadi $78,1 \%$ pada siklus 2, keaktifan siswa dalam perhatian meningkat dari 74,2\% pada siklus 1 menjadi 78,9\% pada siklus 2 dan keaktifan siswa dalam berpendapat meningkat dari $69,5 \%$ pada siklus 1 menjadi 74,2\% pada siklus 2 . Meningkatnya keaktifan siswa dikarenakan dilibatkannya siswa secara langsung dalam penggunaan, pemanfaatan LKS yang menyebabkan siswa tertarik dan juga dapat berinteraksi dengan guru dan siswa lainnya dalam pembelajaran sehingga aktifitas siswa dalam perhatian, bertanya, berpendapat, menjawab, dan berdiskusi meningkat. Hal ini berbeda apabila siswa hanya melihat materi atau konsep saja (Rosarina et al., 2016; Setiani, Koeswanti, \& Radia, 2019).

Kinerja guru dalam proses pembelajaran juga mengalami peningkatan. Pada sklus I persentase kinerja guru dari lima indikator sebesar 68,18\% meningkat sebesar 81,8\%. Ini berarti guru dalam proses pembelajaran sudah berjalan dengan baik. Materi yang diajarkan menggunakan LKS dapat diterima siswa dan dapat dengan mudah di serap. Begitu pula cara guru memberikan permasalahan yang ada pada kehidupan nyata dan melibatkan siswa dalam pembelajaran sudah sangat baik dilakukan, sehingga antara guru dan murid terjadi interaksi yang membuat pembelajaran berjalan dengan efektif (Hidayat, Mawardi, \& Astuti, 2019). Berdasarkan pembahasan di atas, penelitian tindakan kelas dengan menerapkan pembelajaran discovery dapat meningkatkan hasil belajar siswa, keatifan dan ketuntasan belajar siswa dalam pembelajaran juga ikut meningkat.

Hasil penelitian ini diperkuat oleh hasil penelitian yang dilakukan oleh Rosarina et al., (2016), Setiani, Koeswanti, \& Radia (2019) yang menyatakan bahwa aktifitas belajar peserta didik dengan penerapan discovery dapat ditingkatkan dan ditunjukan dengan meningkatnya aktifitas peserta didik di dalam kelas dari siklus yang satu ke siklus berikutnya. Hasil penelitian juga diperkuat oleh Jiwandana (2013), Hidayat, Mawardi, \& Astuti (2019) yang dalam penelitiannya menyatakan bahwa dengan penerapan implementasi metode discovery dapat meningkatkan keaktifan belajar dan hasil belajar siswa dari siklus 1 ke siklus 2 .

\section{PENUTUP}

Berdasarkan hasil penelitian tindakan kelas yang telah dilaksanakan, maka dapat disimpulkan bahwa pembelajaran dengan penerapan discovery dapat meningkatkan hasil belajar siswa. Hal ini ditunjukan dengan peningkatan nilai rata-rata kelas dari hasil evaluasi I siklus I siswa yang tuntas belajar 15 siswa (68\%) dengan rata-rata kelas mencapai 69,5, dan pada siklus II yang tuntas belajar menjadi 22 siswa (88\%) dengan rata-rata kelas mencapai 83,4 . Peningkatan persentase keaktifan dari $71,4 \%$ pada siklus I menjadi $77,3 \%$ pada siklus II; dan peningkatan persentase kinerja guru siklus I sebesar $68,18 \%$ meningkat sebesar $81,8 \%$ pada siklus II. Berdasarkan hasil penelitian tindakan kelas, saran yang dapat diberikan adalah guru hendaknya 
dapat berperan sebagai motivator dan fasilitator serta dapat mengembangkan kreatifitas dan meningkatkan peran siswa dalam pembelajaran.

\section{DAFTAR PUSTAKA}

Arikunto, S. (2010). Metode penelitian. Jakarta: Rineka Cipta.

Hidayat, T., Mawardi, M., \& Astuti, S. (2019). Peningkatan kemampuan berpikir kritis dan hasil belajar siswa kelas IV melalui model pembelaran discovery learning pada tema indahnya keberagamandi negeriku. Judika (Jurnal Pendidikan Unsika), 7(1), 1-9.

Hidhayah, A. P., Slameto, S., \& Radia, E. H. (2018). Peningkatan hasil belajar IPA dengan model pembelajaran discovery learning bagi siswa kelas IV SDN Tingkir Lor 2 Tahun Ajaran 2017/2018. Kalam Cendekia PGSD Kebumen, 6(3.1).

Illahi, M. T. (2012). Pembelajaran dicovery strategy dan mental vocational skill. Jogjakarta: Diva Press

Jiwandana, D. S. (2013). Penggunaan guided discovery learning untuk meningkatkan hasil belajar IPA pada siswa kelas IV SDN Mendalanwangi 01 Wagir-Malang (Doctoral dissertation, University of Muhammadiyah Malang).

Markaban. (2006). Model Pembelajaran dengan pendekatan penemuan terbimbing. Yogyakarta: Departemen Pendidikan Nasional Pusat Pengembangan dan Penataran Guru Matematika.

Putrayasa, I. M., Syahruddin, S. P., \& Margunayasa, I. G. (2014). Pengaruh model pembelajaran discovery learning dan minat belajar terhadap hasil belajar IPA siswa. Mimbar PGSD Undiksha, 2(1).

Rosarina, G., Sudin, A., \& Sujana, A. (2016). Penerapan model discovery learning untuk meningkatkan hasil belajar siswa pada materi perubahan wujud benda. Jurnal Pena Ilmiah, 1(1).

Setiani, R., Koeswanti, H. D., \& Radia, E. H. (2019). Upaya meningkatkan hasil belajar tema 6 dengan model discovery learning pada siswa Kelas IV SD Negeri Cebongan 02 Salatiga. Jurnal Tematik, 9(1), 46-53.

Sudirama, P. P., Japa, I. G. N., \& Yasa, L. P. Y. (2021). Meningkatnya hasil belajar ipa siswa kelas iv sd melalui pembelajaran discovery learning. Journal for Lesson and Learning Studies, 4(2).

Supriyadi, A. (2012). Peningkatan hasil belajar metode discovery pembelajaran IPA kelas IV SDN 03 Sungai Ambawang Kubu Raya. Jurnal Pendidikan dan Pembelajaran Khatulistiwa, 2(8).

Susanti, A. S., Harjono, N., \& Airlanda, G. S. (2018). Perbaikan proses dan hasil belajar muatan IPA melalui model pembelajaran discovery learning (DL) pada siswa kelas IV SD. $e$ Jurnal Mitra Pendidikan, 2(7), 670-682.

Trianto. (2012). Model pembelajaran terpadu. Jakarta: PT Bumi Aksara 